\title{
When elemental carbon turns into carbonate; redox conditions of a carbonate-rich melt source
}

\author{
V. Stagno, D. J. Frost \\ Bayerisches Geoinstitut, Universität Bayreuth, D-95440 Bayreuth, Germany \\ (Vincenzo.Stagno@UNI-BAYREUTH.DE/Phone +49 (0)921-55 3878)
}

\section{INTRODUCTION}

Carbonatites or carbonate-rich melts are likely to be the first liquids produced during mantle up-welling. Though they are implicated in the origin of kimberlitic magmas, it is also possible that mid ocean ridge melting commences with the production of small degree carbonate rich melts at conditions much deeper in the mantle than the main phase of silicate partial melting. There is evidence of deep melting beneath mid ocean ridges from seismological anomalies located beneath the East Pacific Rise (Gu et al, 2005). In a recent study it was proposed that such deep melting occurs as a result of $\mathrm{H}_{2} \mathrm{O}$ and $\mathrm{CO}_{2}$ in the source and that a small concentration of $\mathrm{CO}_{2}$ in the mantle could produce carbonatitic melts as the ridge geotherm intersects the carbonated-peridotite solidus at a depth of approximately $300 \mathrm{~km}$ (Dasgupta et al., 2007). Although the formation of carbonate-bearing melts, including carbonatites and kimberlites, has been well studied in terms of solidus temperature, composition and volatile content (Dalton \& Wood, 1993; Dalton \& Presnall, 1998; Dasgupta et al., 2007), the crucial role of the oxygen fugacity has been somewhat neglected. The oxygen fugacity controls whether carbon exists as carbonate minerals and melts, $\mathrm{CH}_{4}$ species or graphite/diamond species in Earth's interior.

While it is possible that the coexistence of carbonate and graphite/diamond may buffer the oxygen fugacity of the mantle, ferric/ferrous equilibria possibly exert a more dominant influence and may tend to drive the oxygen fugacity of the mantle down with increasing depth (Ballaus, 1995). In this scenario the onset of carbonatitic melting in up-welling mantle will be controlled by the point where the ambient oxygen fugacity crosses the oxygen fugacity imposed by the appropriate carbon - carbonate equilibria, rather than the solidus of carbonate-bearing mantle. In the simplest system such an equilibria is described by the mineral acronym EMOG/D i.e.

$$
\underset{\text { enstatite }}{\mathrm{MgSiO}_{3}}+\underset{\text { magnesite }}{\mathrm{MgCO}_{3}}=\underset{\text { olivine }}{\mathrm{Mg}_{2} \mathrm{SiO}_{4}}+\underset{\text { graph/diam }}{\mathrm{C}}+\underset{\mathrm{O}_{2}}{\text { graph }}
$$

the oxygen fugacity of which can be quite accurately calculated at low pressure using thermodynamic data. A more applicable equilibria in terms of mantle carbonate chemistry, however, is the EDDOG equilibria,

$2 \mathrm{Mg}_{2} \mathrm{Si}_{2} \mathrm{O}_{6}+\mathrm{CaMg}\left(\mathrm{CO}_{3}\right)_{2}=\mathrm{CaMgSi}_{2} \mathrm{O}_{6}+2 \mathrm{Mg}_{2} \mathrm{SiO}_{4}+2 \mathrm{C}+2 \mathrm{O}_{2}$ [2] enstatite melt/dolomite diopside olivine graph/diam where the oxygen fugacity consequently becomes dependent on the purity of the carbonate melt phase above the solidus. As this melt phase becomes more $\mathrm{SiO}_{2}$-rich with increasing temperature the oxygen fugacity will be lowered.

In this study the oxygen fugacity imposed by these equilibria has been measured in the $\mathrm{Fe}-\mathrm{Ca}-\mathrm{Mg}-\mathrm{Si}-\mathrm{C}-\mathrm{O}$ system and in more complex natural systems as a function of pressure and temperature, including conditions where carbonate liquids are stable. The ferrous/ferric ratio of garnet and wadsleyite buffered by such carbon - carbonate equilibria has also been measured.

\section{EXPERIMENTAL METHODS}

The experiments were carried out in a multi anvil apparatus at pressures from 3 to $16 \mathrm{GPa}$ and temperatures from $1250-1500{ }^{\circ} \mathrm{C}$. Mineral starting mixtures of olivine, enstatite, diopside, graphite, $\mathrm{MgCO}_{3}$ and $\mathrm{CaCO}_{3}$ were employed to make mixtures representative of the equilibria [1] and [2]. Metallic iridium was added in small amounts $(5 \mathrm{wt} \%)$ as a redox sensor. $\mathrm{Mg}, \mathrm{Fe}-$ and $\mathrm{Ca}, \mathrm{Fe}, \mathrm{Mg}$ - bearing garnets were synthesized as glasses at $1600^{\circ} \mathrm{C}$ and then reduced in a gas mixing furnace. A garnet layer was added to some experiments sandwiched between one of the two buffering assemblages given by [1] and [2] (see fig. 1). Some experiments were carried out by mixing $10 \%$ of the buffering assemblage within the garnet layer to ensure the equilibrium.

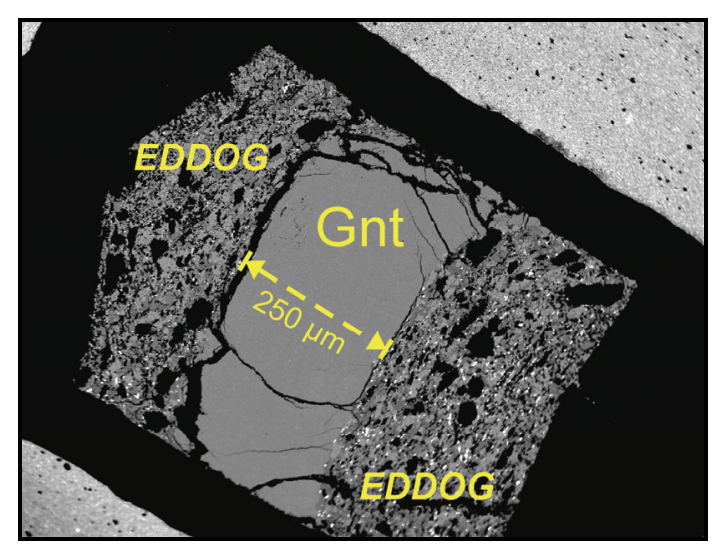

Figure 1. Back Scattered Electron image of a garnet layer sandwiched between assemblage [2] from $7 \mathrm{GPa}$ and $1400{ }^{\circ} \mathrm{C}$.

Starting mixtures were placed in graphite capsules inside outer Re foil sleeves. 
Textural observations of the run products were performed by scanning electron microscope. The chemical composition of the melts and mineral phases were obtained using a Jeol JXA-8200 electron microprobe.

The ferric iron contents of the garnet layers were determined by ${ }^{57}$ Mössbauer spectroscopy. The spectra were collected at room temperature and fit using the Normos software.

\section{OXYGEN FUGACITY}

In this study oxygen fugacities imposed by the carbon carbonate equilibrium were experimentally measured by using Ir-Fe alloy as a redox sensor (Swartzendruber, 1984; Woodland \& O’Neill, 1997).

The oxygen fugacity was determined using the equilibrium,

$$
\underset{\text { olivine }}{2 \mathrm{Fe}_{2} \mathrm{SiO}_{4}}=\underset{\text { enstatite }}{2 \mathrm{FeSiO}_{3}}+\underset{\text { alloy }}{2 \mathrm{Fe}}+\mathrm{O}_{2}
$$

where the oxygen fugacity is calculated using,

$\log f_{2}=\frac{-\Delta G^{o}}{\ln (10) R T}+2 \log a_{\mathrm{Fe}_{2} \mathrm{SiO}_{4}}^{\mathrm{Ol}_{4}}-2 \log a_{\mathrm{FeSi}_{3}}^{\text {enstatite }}-2 \log a_{\mathrm{Fe}}^{\text {metal }}$

with $a_{i}^{j}$ the activity of component $i$ in phase $j$ of the run products estimated by microprobe measurements and by employing an appropriate activity-composition model. During the experiment Fe alloys with the $\mathrm{Ir}$ metal to equilibrate with the oxygen fugacity imposed by the equilibrium between carbonate minerals/melts and graphite/diamond. Experimental results up to 7 $\mathrm{GPa}$ are shown in figure 2 and are compared to literature data on the $f \mathrm{O}_{2}$ recorded by garnet-bearing mantle xenoliths. The determined $f \mathrm{O}_{2}$ as function of pressure (fig.2) is in approximate agreement with the determinations of Eggler and Baker, 1982.

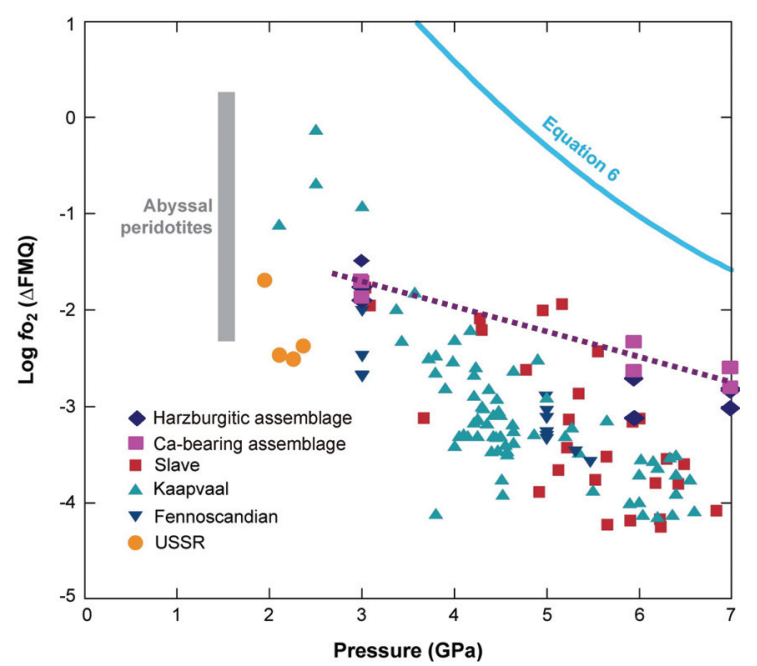

Figure 2. The experimentally determined oxygen fugacity of the carbon - carbonate equilibria in Ca-bearing and Ca-free systems is shown as a function of depth by the pink and blue symbols and the dotted line. $f_{\mathrm{O}_{2}}$ calculated for garnet peridotite xenoliths from sources given in Frost \& McCammon (2008) are also shown.

The experiments show that the $f \mathrm{O}_{2}$ of both equilibria [1] and [2] continues to drop with a similar slope as observed in figure 2 to conditions well into the wadsleyite stability field (16 GPa).

\begin{tabular}{ccccc} 
Table 1 & \multicolumn{5}{l}{} \\
\hline & $\begin{array}{c}\mathrm{P} \\
(\mathrm{GPa})\end{array}$ & $\begin{array}{c}\mathrm{T} \\
\left({ }^{\circ} \mathrm{C}\right)\end{array}$ & $\mathrm{Fe} /(\mathrm{Fe}+\mathrm{Mg}+\mathrm{Ca})$ & $\begin{array}{c}\mathrm{Fe}^{3+} / \\
\sum \mathrm{Fe}(\%)\end{array}$ \\
\hline Garnet & 7 & 1400 & 0.15 & 12 \\
Ca-free Garnet & 7 & 1400 & 0.2 & 5 \\
Wadsleyite & 16 & 1500 & 0.12 & 4 \\
\hline
\end{tabular}

\section{FERRIC IRON CONTENTS}

The results of Mössbauer measurements on layers of garnet and wadsleyite in experiments buffered by reactions [1] and [2] are given in table 1. The staring materials for these layers were ferric iron free but Mössbauer spectra confirmed the oxidation of iron in these phases as shown in figure 3 and 4 .

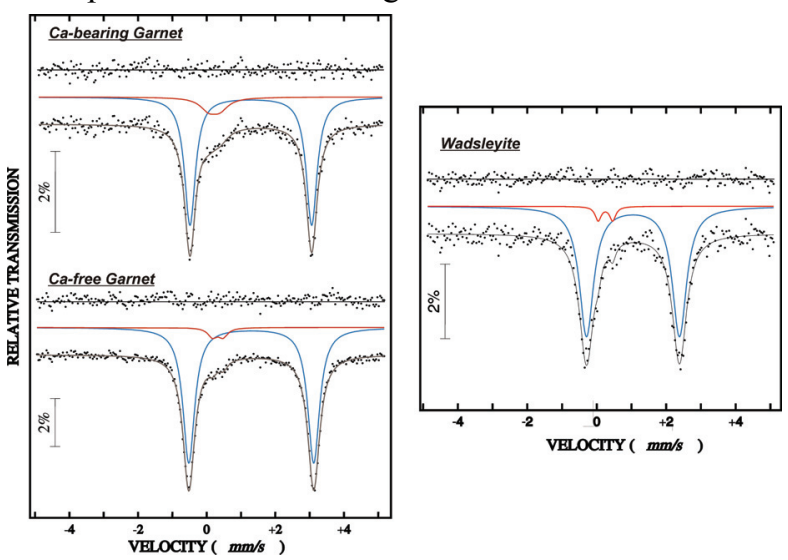

Figure 3-4. The Mössbauer spectra confirm the occurring of $\mathrm{Fe}^{3+}$ after the experiments on starting materials that initially contained only $\mathrm{Fe}^{2+}$.

The oxidation of $\mathrm{Fe}^{2+}$ by the reduction of carbonate can be observed in the garnet layers where graphite inclusions developed, as shown in Figure 5.

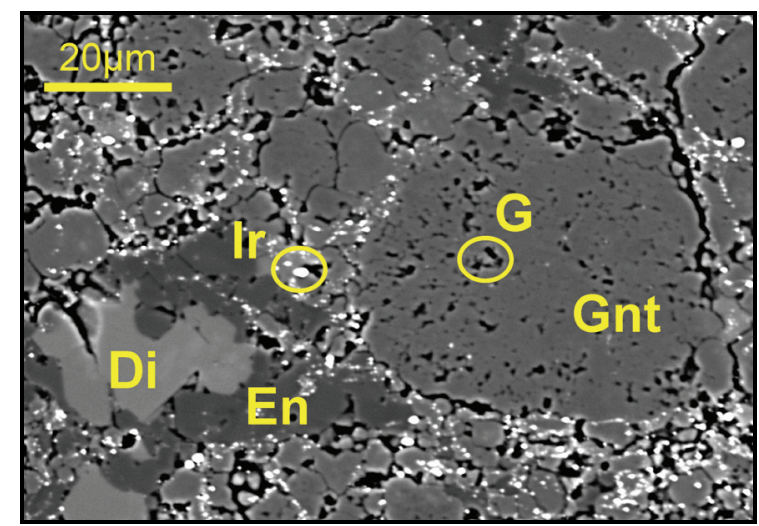

Figure 5. Recovered experiment from $7 \mathrm{GPa}$ and $1400{ }^{\circ} \mathrm{C}$ in the presence of melt showing the development of graphite inclusions as a result of carbonate reduction. $G$ is graphite, Gnt garnet, Di diopside, En enstatite.

The $\mathrm{Fe}^{3+} / \sum \mathrm{Fe}$ ratio measured for Ca-bearing garnets in these experiments is similar to values found for some natural garnet samples from similar pressures (Luth et al. 1990). As shown in figure 7, however, the $f \mathrm{O}_{2}$ 
determined for such samples using the oxythermobarometer of Gudmundsson and Wood (1995) is lower by 1 log unit than the level buffered in these experiments by the carbon/carbonate equilibria. From the experiments the $\mathrm{Fe}^{3+} / \sum \mathrm{Fe}$ ratios in wadsleyite were found to be relatively low $(\sim 4 \%)$ given that, the buffering $f \mathrm{O}_{2}$ is $3 \mathrm{log}$ units above the iron-wüstite (IW) buffer. Previous experiments have reported $\mathrm{Fe}^{3+} / \sum \mathrm{Fe}$ ratios of $\sim 2 \%$ in wadsleyite at oxygen fugacities below the IW buffer (O’Neill et al. 1993).

\section{MELT COMPOSITION}

The melt exhibited a typical quenched texture (fig. 6), and was compositionally inhomogeneous. Melts migrated to the sample/capsule interface and in many instances were absorbed into the graphite capsule.

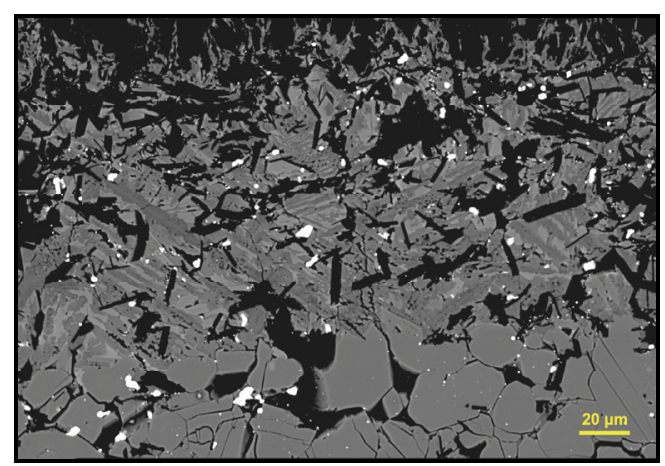

Figure 6. Scanning electron microscope image of a recovered experiment at $3 \mathrm{GPa}-1350{ }^{\circ} \mathrm{C}$ showing a quenched melt texture with laths of graphite and iridium metal. Grains of enstatite and olivine can be seen in the bottom of the image.

With increasing temperature melts were observed to become more Si rich. This was accompanied by a drop in $\mathrm{fO}_{2}$ as the carbonate melt becomes diluted with silicate material. As shown in figure 7 , as the melt silicate content increases from 2 to $25 \mathrm{wt} \%$ the $f_{2}$ drops by $0.3-0.4 \log$ units.

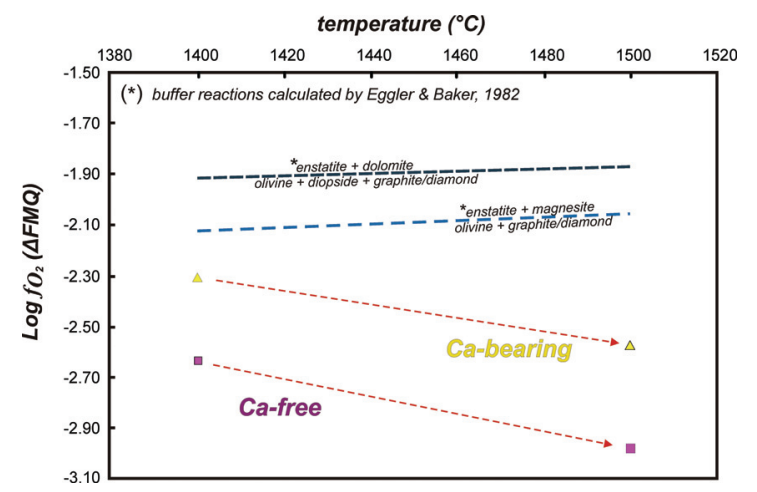

Figure 7. The $f \mathrm{O}_{2}$ of carbonate melt bearing assemblages in $\mathrm{Ca}$ and $\mathrm{Ca}$ free systems as a function of temperature at $6 \mathrm{GPa}$. Melt $\mathrm{SiO}_{2}$ content increases from $2 \mathrm{wt} \%$ at the solidus to $25 \mathrm{wt} \%$ at $1500^{\circ} \mathrm{C}$. Determinations for the solid buffering assemblages from Eggler and Baker (1982) are shown for comparison.

\section{CONCLUSIONS}

The oxygen fugacity imposed by the equilibrium between carbonate minerals, melts and graphite/diamond in Ca-bearing and $\mathrm{Ca}$-free systems has been determined between 3-16 GPa.
Oxygen fugacities for subsolidus assemblages are in broad agreement with those determined by Eggler and Baker (1982), however, the onset of melting drives the equilibrium oxygen fugacities down as the carbonate melts become Si-rich with increasing temperature. The effect of melt composition on the carbon/carbonate $\mathrm{fO}_{2}$ is relatively modest and up welling mantle should not cross into the carbonate mineral or melt stability field at pressures higher than approximately $4 \mathrm{GPa}$.

Preliminary measurements of $\mathrm{Fe}^{3+} / \sum \mathrm{Fe}$ ratios of garnets in equilibrium with graphite and carbonate are slightly inconsistent with the predictions of oxythermobarometers. Wadsleyite $\mathrm{Fe}^{3+} / \sum \mathrm{Fe}$ ratios from experiments buffered at similar levels are low compared to values measured at IW, implying that high levels of ferric iron may not be necessary for the development of carbonate bearing assemblages in the transition zone.

\section{ACKNOWLEDGMENTS}

This research is supported by the Marie Curie Project and the Bayerisches Geoinstitut. C. McCammon is thanked for her help with Mössbauer measurements.

\section{REFERENCES}

Ballhaus C. 1995. Is the upper mantle metal-saturated? Earth and Planetary Science Letters 132, 75-86.

Dalton, J. A. and Presnall, D. C., 1998b. The continuum of primary carbonatitic-kimberlitic melt compositions in equilibrium with lherzolite: data from the system $\mathrm{CaO}-\mathrm{MgO}-\mathrm{Al}_{2} \mathrm{O}_{3}-$ $\mathrm{SiO}_{2}-\mathrm{CO}_{2}$ at $6 \mathrm{GPa}$. Journal of Petrology 39, 1953-1964.

Dalton J. A. and Wood B. J., 1993. The compositions of primary carbonate melts and their evolution through wallrock reaction in the mantle. Earth and Planetary Science Letters $119,511-525$.

Dasgupta R., Hirschmann, Smith N., 2007. Water follows carbon: $\mathrm{CO}_{2}$ incites deep silicate melting and dehydration beneath mid-ocean ridges. Geology 35 (2), 135-138.

Eggler D. H. and Baker D. R., 1982. Reduced volatiles in the system C-O-H: implications to mantle melting, fluid formation, and diamond genesis. High-Pressure Research in Geophysics, 237-250.

Frost D. J. and McCammon C. A., 2008. The redox state of the Earth's mantle. Annual Review of Earth and Planetary Science 36, 389-420.

Gu, Y. J., Lerner-Lam A. L., Dziewonski A. M., Ekstrom, G, 2004. Deep structure and seismic anisotropy beneath the East Pacific Rise. Earth and Planetary Science Letters 232, 259272.

Gudmundsson G. and Wood B. J., 1995. Experimental tests of garnet peridotite oxygen barometry. Contributions to Mineralogy and Petrology 119, 56-67.

Luth R. W., Virgo D., Boyd F. R., Wood B. J., 1990. Ferric iron in mantle-derived garnets. Contributions to Mineralogy and Petrology 104, 56-72.

McCammon C. A., Kopylova M. G., 2004. A redox profile of the Slave mantle and oxygen fugacity control in the cratonic mantle. Contributions to Mineralogy and Petrology 148, 5568.

O’Neill H. St. C., McCammon C. A., Canil D., Rubie D. C., Ross C. R.II, Seifert F., 1993. Mössbauer spectroscopy of mantle transition zone phases and determination of minimum $\mathrm{Fe}^{3+}$ content. American Mineralogist 78, 456-460.

Swartzendruber L.J., 1984. The Fe-Ir (iron - iridium) system. Bulletin of Alloy Phase Diagrams 5, 48-52.

Woodland A. B. and O’Neill H. St. C., 1997. Thermodynamic data for Fe-bearing phases obtained using noble metal alloys as redox sensors. Geochimica et Cosmochimica Acta 61 No.20, 4359-4366. 